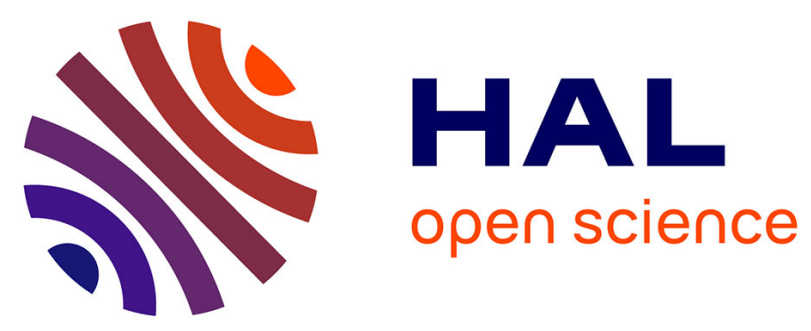

\title{
Carbon storage in biomass, litter, and soil of different plantations in a semiarid temperate region of northwest China
}

Yang Gao, Jimin Cheng, Zhengrui Ma, Yu Zhao, Jishuai Su

\section{- To cite this version:}

Yang Gao, Jimin Cheng, Zhengrui Ma, Yu Zhao, Jishuai Su. Carbon storage in biomass, litter, and soil of different plantations in a semiarid temperate region of northwest China. Annals of Forest Science, 2014, 71 (4), pp.427-435. 10.1007/s13595-013-0355-z . hal-01101768

\author{
HAL Id: hal-01101768 \\ https://hal.science/hal-01101768
}

Submitted on 9 Jan 2015

HAL is a multi-disciplinary open access archive for the deposit and dissemination of scientific research documents, whether they are published or not. The documents may come from teaching and research institutions in France or abroad, or from public or private research centers.
L'archive ouverte pluridisciplinaire HAL, est destinée au dépôt et à la diffusion de documents scientifiques de niveau recherche, publiés ou non, émanant des établissements d'enseignement et de recherche français ou étrangers, des laboratoires publics ou privés. 


\title{
Carbon storage in biomass, litter, and soil of different plantations in a semiarid temperate region of northwest China
}

\author{
Yang Gao $\cdot$ Jimin Cheng $\cdot$ Zhengrui Ma $\cdot$ Yu Zhao $\cdot$ \\ Jishuai Su
}

Received: 7 July 2013 / Accepted: 10 December 2013 /Published online: 24 January 2014

(C) INRA and Springer-Verlag France 2014

\begin{abstract}
- Context A large area of abandoned land in the semiarid temperate region of China has been converted into plantations over the past decades. However, little information is available about the ecosystem $\mathrm{C}$ storage in different plantations.

- Aim and methods Our objective was to estimate the $\mathrm{C}$ storage in biomass, litter, and soil of four different plantations (monospecific stands of Larix gmelinii, Pinus tabuliformis, Picea crassifolia, and Populus simonii). Tree component biomass was estimated using allometric equations. The biomasses of understory vegetation and litter were determined by harvesting all the components. $\mathrm{C}$ fractions of plant, litter, and soil were measured.

- Results The ecosystem C storage were as follows: Picea crassifolia (469 t C/ha) $>$ Larix gmelinii ( $375 \mathrm{t} \mathrm{C/ha),} \mathrm{Populus}$ simonii $(330 \mathrm{t} \mathrm{C/ha)}>$ Pinus tabuliformis $(281 \mathrm{t} \mathrm{C/ha})$ $(P<0.05), 59.5-91.1 \%$ of which was in the soil. The highest tree and understory $\mathrm{C}$ storage were found in the plantation of Pinus tabuliformis (247 t/ha) and Larix gmelinii (1.2 t/ha) respectively. The difference in tree $\mathrm{C}$ fraction was significant among tree components $(P<0.05)$, following the order: leaf $>$ branch $>$ trunk $>$ root. The highest soil C (SC) was stored in Picea crassifolia plantation (411 t C/ha), while Populus
\end{abstract}

Handling Editor: Shuqing Zhao

Y. Gao $\cdot$ J. Cheng $\cdot$ J. Su

College of Animal Science and Technology, Northwest A\&F

University, Yangling 712100, Shaanxi, People's Republic of China

J. Cheng $(\bowtie) \cdot$ Z. Ma

Institute of Soil and Water Conservation, Northwest A\&F University,

26 Xinong Road, Yangling, Shaanxi 712100,

People's Republic of China

e-mail: gyzcjm@ms.iswc.ac.cn

Y. Zhao

College of Life Sciences, Northwest A\&F University,

712100 Yangling, Shaanxi, People's Republic of China simonii plantation had a higher SC sequestration rate than others.

- Conclusion C storage and distribution varied among different plantation ecosystems. Coniferous forests had a higher live biomass and litter $\mathrm{C}$ storage. Broadleaf forests had considerable SC sequestration potential after 40 years establishment.

Keywords Biomass carbon $\cdot$ Litter $\cdot$ Semiarid region $\cdot$ Soil carbon $\cdot$ Tree species $\cdot$ Understory vegetation

\section{Introduction}

The forest ecosystems have large potential to act as a temporary and long-term carbon (C) pool (Dixon et al. 1994). Approximately $80 \%$ aboveground and $40 \%$ underground terrestrial C are stored in forests (Cao and Woodward 1998). However, in the temperate semiarid region of northwest China, many natural forests are degraded to abandoned lands because of climate change and human disturbance. The Chinese government has imposed the 'Grain-for-Green' project (i.e., conversion of cropland to forest and grassland) since 1999 (Zhang et al. 2010). Large areas of abandoned land have been converted into forest lands (Fang et al. 2001). Establishment of forest plantation contributes to soil and water conservation, and biodiversity protection (Chazdon 2008). Also, afforestation is regarded as an effective measure to prevent the global warming by sequestrating $\mathrm{C}$ both in biomass and in soil. Trees and understory vegetation assimilate carbon dioxide $\left(\mathrm{CO}_{2}\right)$ from the atmosphere and store $\mathrm{C}$ in plant biomass. Accordingly, the storage of soil carbon (SC) increases with the large amount of $\mathrm{C}$ input from litterfall and rhizodeposition (Vesterdal et al. 2012).

The magnitude and progress of the changes in C storage following afforestation are highly various because of the influence of different factors, such as climatic condition, soil 
property, tree species, and present management (Jobbágy and Jackson 2000; Paul et al. 2002). Among them, tree species strongly affect the $\mathrm{C}$ accumulation of plantation ecosystems in several ways (Díaz-Pinés et al. 2011). Firstly, tree species influences the $\mathrm{C}$ storage of live biomass as a result of different tree traits. One of the most determinant tree traits is the growth rate. Fast-growing species, such as poplar, pine, and eucalypt are widely planted for C sequestration (Kaul et al. 2010). However, the fast biomass increment brings in a lower $\mathrm{C}$ fraction, suggesting that planting fast-growing tree species sacrifices some $\mathrm{C}$ gain by decreasing their $\mathrm{C}$ fraction (Zhang et al. 2009). The species-specific $C$ fraction imposes its effect on biomass $\mathrm{C}$ storage by varying with growth rates. Moreover, $\mathrm{C}$ sequestration in trees is also influenced by the variation of wood density. At identical volume, trees with higher wood density (most deciduous species) accumulate more $\mathrm{C}$ than those with light wood density (most coniferous species) (Jandl et al. 2007).

Secondly, interspecific differences in the production and decomposition rate of litters explain the variations in litter $\mathrm{C}$ storage (Finzi et al. 1998). Deciduous tree species have a higher annual production of litters than the evergreen coniferous species. However, previous research showed that pine and spruce had more litter C than beech and oak (Jandl et al. 2007). It is mainly attributed to the slow decay rate of needle litters determined by the chemical composition, such as soluble carbohydrates and lignin concentrations (Paul et al. 2002). The decay of litters not only depends on its own property, but also on stand microclimatic conditions. Pérez-Cruzado et al. (2012) demonstrated that light transmission was higher in Eucalyptus than in Pinus stands determined by the arrangement of the leaves. The higher light transmission leads to a favorable soil temperature and moisture level for decomposers, and then promotes the decay of litters (Martius et al. 2004).

Finally, tree species also influences the amount, quality, and distribution of soil C (SC) by regulating $\mathrm{C}$ input (litterfall and rhizodeposition) and $\mathrm{C}$ output (respiration and leaching) (Vesterdal et al. 2012). For instance, pine forests have remarkably low SC storage, whereas beech forests have the highest SC storage among common European tree species (Jandl et al. 2007). As mentioned above, coniferous forest had lower litter decomposition rate than deciduous forest, slowing down the $\mathrm{C}$ input from litter to the soil. Moreover, the rooting depth is relevant for $\mathrm{SC}$, because root growth is the most effective way of introducing $C$ to the soil (Jobbágy and Jackson 2000). Coniferous species with shallow roots tended to accumulate less $\mathrm{C}$ in the soil. In addition, Vesterdal et al. (2012) reported that the soil respiration increased in the order beech $<$ lime $<$ spruce, oak, maple $<$ ash. Thus, C outputs by soil respiration of different tree species were various, which partly influenced the SC storage.

Recently, many case studies involved in forest ecosystem $\mathrm{C}$ storage and dynamics have been conducted by Chinese researchers, using forestry survey data (Fang et al. 2001; Guo et al. 2010). However, studies about $\mathrm{C}$ storage of plantation ecosystems in the semiarid region are scarce, and the quantification of total plant biomass $\mathrm{C}$, including understory vegetation and litter, is even rarer. The objectives of this study were (1) to find which plantation ecosystem has higher $\mathrm{C}$ sequestration capacity, and (2) to explore the distribution of $\mathrm{C}$ storage in the plant biomass, litter, and soil. The information concerning $\mathrm{C}$ storage at the ecosystem level would provide more accurate assessments of the $\mathrm{C}$ sequestration.

\section{Materials and methods}

\subsection{Study area}

The study was carried out in Ningxia Hui Autonomous Region (northwest China), which has a continental climate. The mean annual temperature is between $5{ }^{\circ} \mathrm{C}$ and $9{ }^{\circ} \mathrm{C}$. The mean monthly maximum temperature is in July, and the mean monthly minimum temperature is in January. The mean annual precipitation is between $180 \mathrm{~mm}$ and $800 \mathrm{~mm}$. The majority of precipitation falls during the period July to September. Typical soil types in the region are gray cinnamon soil, black loam, and aeolian soil. The average $\mathrm{pH}$ of soil here ranges between 6.5 and 8.5 (Sun et al. 2009). Plantations here are monospecific stands dominated by larch, pine, spruce, poplar and etc. The understory shrub species are Cotoneaster acutifolius, Corylus heterophylla, Spiraea mongolica, Elaeagnus pungens, Lonicera microphylla, Sorbaria sorbifolia and etc. The understory herb species are Eragrostis pilosa, Cymbopogon citrates, Fragaria orientalis, Carex duriuscula, Heteropappus altaicus, Artemisia subdigitata and etc.

\subsection{Experimental setup, sampling, and laboratory analysis}

Larix gmelinii, Pinus tabuliformis, Picea crassifolia, and Populus simonii stands were selected as tested sites. Abandoned lands (the initial land use before afforestation) in the main experiment area served as control sites (Table 1). In each plantation and control site, three replicated $50 \mathrm{~m} \times 20 \mathrm{~m}$ plots (at least $100 \mathrm{~m}$ away from each other) were established. Each plot was separated into ten $10 \mathrm{~m} \times 10 \mathrm{~m}$ quadrats. In all the quadrats, the height and diameter at breast height (DBH) for each individual tree were measured to estimate tree biomass. Five samples of tree leaf, branch, trunk, and root were randomly collected for $\mathrm{C}$ fraction determination. All understory vegetation (shrub and herb) was harvested from three subquadrats $(2 \mathrm{~m} \times 2 \mathrm{~m})$ randomly located in each quadrat. Shrubs were separated into leaves, branches, and roots; herbs were separated into aboveground and belowground parts. All litter was collected from three subquadrats $(1 \mathrm{~m} \times 1 \mathrm{~m})$ located within each quadrat. Samples of understory vegetation and 
Table 1 Description of the study sites

\begin{tabular}{|c|c|c|c|c|c|}
\hline Site & Property & & & & \\
\hline \multicolumn{6}{|c|}{ Plantation } \\
\hline & Tree species & Larix gmelinii & Pinus tabuliformis & Picea crassifolia & Populus simonii \\
\hline & Altitude (m) & 2,300 & 2,150 & 2,710 & 2,080 \\
\hline & Forest type & Deciduous & Evergreen & Evergreen & Deciduous \\
\hline & & Conifer forest & Conifer forest & Conifer forest & Broadleaf forest \\
\hline & Soil type & Gray cinnamon soil & Gray cinnamon soil & Gray cinnamon soil & Gray cinnamon soil \\
\hline & Stand age (a) & 46 & 32 & 48 & 40 \\
\hline & Density (tree/ha) & $1,520 \pm 64$ & $2,830 \pm 256$ & $1,570 \pm 144$ & $1,420 \pm 51$ \\
\hline & $H(\mathrm{~m})$ & $12.8 \pm 0.3$ & $15.0 \pm 1.0$ & $12.4 \pm 3.1$ & $7.4 \pm 0.8$ \\
\hline & $D(\mathrm{~cm})$ & $10.8 \pm 0.2$ & $7.9 \pm 0.7$ & $6.9 \pm 1.6$ & $5.8 \pm 0.6$ \\
\hline \multicolumn{6}{|c|}{ Control } \\
\hline & Land use & Abandoned land & Abandoned land & Abandoned land & Abandoned land \\
\hline & Vegetation type & Grassland & Grassland & Grassland & Grassland \\
\hline & Soil type & Gray cinnamon soil & Gray cinnamon soil & Gray cinnamon soil & Gray cinnamon soil \\
\hline
\end{tabular}

Data of density, $H$ and $D$ represent the mean \pm standard deviation

$H$ is tree height, $D$ is diameter at breast height

litter were dried at $65^{\circ} \mathrm{C}$ to constant weight for determination of biomass and $\mathrm{C}$ fraction.

Ten representative soil samples were randomly collected for each plot $(50 \mathrm{~m} \times 20 \mathrm{~m})$ at depths of 0-10 cm, 10-20 cm, $20-30 \mathrm{~cm}, 30-50 \mathrm{~cm}$, and $50-100 \mathrm{~cm}$ using a soil core $(5 \mathrm{~cm}$ diameter). Soil samples from the same layer in each plot (plantation plots and control plots) were mixed for a more representative sample for the measurement of soil $\mathrm{C}$ (SC) fraction. In addition, soil cores (5-cm-height, 5-cm-diameter) with two replications of each plot were sampled for bulk density measurement as suggested by the Chinese Editorial Committee of Soil Analysis (1996).

The plant, litter, and soil samples were dried and ground to pass through $0.25-\mathrm{mm}$ sieve prior to the laboratory analysis. The $\mathrm{C}$ fraction was determined using an Elementar Vario EL cube Analyzer.

\subsection{Destructive tree sampling}

To estimate the biomass of tree components, we harvested 20 trees of each species in the sites with similar characteristics to the study area. These trees were selected with the aim of covering the range of DBH from $5 \mathrm{~cm}$ to $40 \mathrm{~cm}$. Stems were cut at the ground level. Total tree height and DBH were measured and recorded. The trunk was marked into three parts (top, middle, and bottom), cut into $1 \mathrm{~m}$ sections, and weighed. At the end of each trunk section, a $5-\mathrm{cm}$ thick disc was cut, weighed, and taken to laboratory for moisture content determination. Branches were also separated into three different size components (diameter $>20 \mathrm{~cm}, 5-20 \mathrm{~cm}$, and $<5 \mathrm{~cm}$ ). All the leaves were collected in the field. The stump and coarse root (diameter $\geq 5 \mathrm{~mm}$ ) of sample trees was excavated manually. The fresh weight of each component (trunk, branch, leaf, and root) was measured to the nearest $1.0 \mathrm{~g}$ by using an electronic balance. Approximately $500 \mathrm{~g}$ of fresh samples of each tree component were randomly collected for moisture content determination. Dry weight was obtained by drying the samples at $65{ }^{\circ} \mathrm{C}$ until they reached a constant weight. The total dry biomass of each component was calculated through multiplying the fresh weight by the dry/wet ratio. Biomass for the whole tree was calculated by summing the biomass of trunk, branch, leaf, and root.

\subsection{Data analysis}

Statistical analysis was performed by the software SPSS, ver. 16.0 (SPSS Inc., Chicago, IL, USA). Allometric equations between tree component biomass and independent variable (squared DBH multiplied by the tree height $\left(D^{2} H\right)$ ) were developed using curve fitting. The optimum equations were selected to calculate the tree component biomass in the plantation sites. Plant and litter $\mathrm{C}$ storage were calculated from the $\mathrm{C}$ fraction multiplied by component biomass. SC storage was calculated from the SC fraction multiplied by the bulk density and the thickness of the soil layer. SC sequestration rate was calculated by subtracting the SC storage of the control site from that of the plantation and then dividing the result by stand age. ANOVA analyses were used to determine the statistically significance differences between species for the biomass, $\mathrm{C}$ fraction, and $\mathrm{C}$ storage; multiple comparisons were carried out by Duncan's method, with differences in the $P<0.05$ significance level. 
Table 2 Allometric equations for different tree species and component

\begin{tabular}{lllll}
\hline Tree component & Allometric equations & $R^{2}$ & SEE & $F$ \\
\hline Larix gmelinii & & & & \\
$\quad$ Leaf & $\mathrm{B}=0.113\left(D^{2} H\right)^{0.406}$ & 0.841 & 0.282 & $184.391^{* * *}$ \\
Branch & $\mathrm{B}=0.373\left(D^{2} H\right)^{0.397}$ & 0.920 & 0.187 & $184.149^{* * *}$ \\
Trunk & $\mathrm{B}=0.241\left(D^{2} H\right)^{0.552}$ & 0.933 & 0.236 & $223.137^{* * *}$ \\
Root & $\mathrm{B}=1.011\left(D^{2} H\right)^{0.321}$ & 0.813 & 0.246 & $69.347^{* * *}$ \\
Whole tree & $\mathrm{B}=1.282\left(D^{2} H\right)^{0.465}$ & 0.962 & 0.147 & $406.789^{* * *}$ \\
Pinus tabuliformis & & & & \\
Leaf & $\mathrm{B}=0.007\left(D^{2} H\right)^{0.890}$ & 0.896 & 0.412 & $164.088^{* * *}$ \\
Branch & $\mathrm{B}=0.001\left(D^{2} H\right)^{1.246}$ & 0.924 & 0.486 & $231.508^{* * *}$ \\
Trunk & $\mathrm{B}=0.016\left(D^{2} H\right)^{1.020}$ & 0.911 & 0.435 & $193.603^{* * *}$ \\
Root & $\mathrm{B}=0.005\left(D^{2} H\right)^{1.060}$ & 0.963 & 0.284 & $489.867^{* * *}$ \\
Whole tree & $\mathrm{B}=0.031\left(D^{2} H\right)^{1.039}$ & 0.938 & 0.364 & $287.694^{* * *}$ \\
Picea crassifolia & & & & \\
Leaf & $\mathrm{B}=0.056\left(D^{2} H\right)^{0.608}$ & 0.918 & 0.251 & $212.772^{* * *}$ \\
Branch & $\mathrm{B}=1.334\left(D^{2} H\right)^{0.421}$ & 0.826 & 0.267 & $90.369^{* * *}$ \\
Trunk & $\mathrm{B}=0.073\left(D^{2} H\right)^{0.805}$ & 0.912 & 0.346 & $197.608^{* * * *}$ \\
Root & $\mathrm{B}=0.193\left(D^{2} H\right)^{0.617}$ & 0.832 & 0.384 & $94.062^{* * * *}$ \\
Whole tree & $\mathrm{B}=1.026\left(D^{2} H\right)^{0.602}$ & 0.899 & 0.280 & $168.304^{* * *}$ \\
Populus simonii & & & & \\
Leaf & $\mathrm{B}=1.264\left(D^{2} H\right)^{0.262}$ & 0.734 & 0.464 & $37.810^{* * * *}$ \\
Branch & $\mathrm{B}=1.017\left(D^{2} H\right)^{0.472}$ & 0.776 & 0.554 & $24.204^{* * *}$ \\
Trunk & $\mathrm{B}=0.464\left(D^{2} H\right)^{0.646}$ & 0.884 & 0.484 & $57.222^{* * *}$ \\
Root & $\mathrm{B}=0.483\left(D^{2} H\right)^{0.550}$ & 0.809 & 0.498 & $30.294^{* * *}$ \\
Whole tree & $\mathrm{B}=1.973\left(D^{2} H\right)^{0.561}$ & 0.835 & 0.354 & $80.870^{* * *}$ \\
\hline & & & & \\
\hline
\end{tabular}

$D^{2} H$ is squared $\mathrm{DBH}(D,(\mathrm{~cm}))$ multiplied by tree height $(H,(\mathrm{~m})), B$ is the biomass of tree component ( $\mathrm{kg} / \mathrm{tree}), S E E$ is the standard error of estimate *** means the equation is significant $(\alpha=0.001)$

\section{Results}

\subsection{Biomass and $\mathrm{C}$ storage of tree layer}

According to the component allometric equations (Table 2), we estimated the tree biomass of different plantations. Individual tree biomass $(\mathrm{kg} /$ tree) followed the order Pinus tabuliformis $>$ Picea crassifolia $>$ Populus simonii $>$ Larix gmelinii (Table 3), and annual biomass increment was $2.7 \pm$ $0.4 \mathrm{~kg} /$ tree/year, $1.4 \pm 0.1 \mathrm{~kg} /$ tree/year, $1.5 \pm 0.2 \mathrm{~kg} /$ tree $/$ year, and $0.8 \pm 0.2 \mathrm{~kg} /$ tree/year respectively. There was a common tendency for all the species that trunk is a large proportion of tree biomass. This pattern was particularly evident in Pinus tabuliformis, whose trunk represented $55.8 \%$ of the total biomass. Biomass of leaves in all the four plantations was relatively small, accounting for $5.9-12.8 \%$ of the total biomass. Picea crassifolia and Populus simonii had higher branch proportion, while Larix gmelinii had extremely higher root proportion when compared with other tree species.

There were significant interspecific differences in the stand tree biomasses $(F=9.577, P=0.005)$ and $\mathrm{C}$ storage $(F=12.072$, $P=0.002$ ) (Fig. 1). The stand tree biomass was 56 tha in the Larix gmelinii plantation, $247 \mathrm{t} / \mathrm{ha}$ in the Pinus tabuliformis plantation, 106 t/ha in the Picea crassifolia plantation, and 146 tha in the Populus simonii plantation. Accordingly, tree C storage decreased in the order of Pinus tabuliformis $>$ Picea crassifolia $>$ Populus simonii $>$ Larix gmelinii. Two-way ANOVA analysis showed that the difference in tree $\mathrm{C}$ fraction was not statistically significant among the tree species $(P>0.05)$, but significant among the tree components $(P<0.05)$ (Table 4). C fraction of different tree components decreased following the order leaf $>$ branch $>$ trunk $>$ root.

\subsection{Biomass and C storage of understory layer}

Shrub biomass ranged between $1.0 \mathrm{t} / \mathrm{ha}$ and $2.4 \mathrm{t} / \mathrm{ha}$, and decreased as following order, Picea crassifolia, Populus simonii, Larix gmelinii $>$ Pinus tabuliformis $(F=32.960$, $P<0.001)$. Shrub branch generally contributed to higher biomass proportion than leaf or root did in three plantations (Picea crassifolia, Larix gmelinii and Pinus tabuliformis). Whereas shrub roots of Populus simonii plantation had the highest biomass proportion (Fig. 2). Herb biomass was quite various among plantations $(F=39.880, P<0.001)$, ranging between $0.3 \mathrm{t} / \mathrm{ha}$ and $1.0 \mathrm{t} / \mathrm{ha}$. The belowground biomass of herb was about twice of the aboveground biomass.

The Picea crassifolia plantation had significantly lower shrub $\mathrm{C}$ fraction than other plantations (Table 5). For different

Table 3 Biomass of tree components $(\mathrm{kg} / \mathrm{tree})$ of different plantations

\begin{tabular}{llllll}
\hline Tree species & \multicolumn{2}{l}{ Tree component } & & Total tree \\
\cline { 2 - 5 } & Leaf & Branch & Trunk & Root \\
\hline Larix gmelinii & $2.1 \pm 0.2(5.7)$ & $6.6 \pm 0.6(17.6)$ & $13.5 \pm 1.8(45.4)$ & $10.3 \pm 0.8(27.3)$ \\
Pinus tabuliformis & $6.1 \pm 0.4(7.1)$ & $15.0 \pm 1.7(17.4)$ & $47.9 \pm 3.4(55.8)$ & $16.8 \pm 1.6(19.6)$ & $37.5 \pm 4.2 \mathrm{c}$ \\
Picea crassifolia & $4.0 \pm 0.1(5.9)$ & $25.2 \pm 0.6(36.9)$ & $24.2 \pm 1.0(35.6)$ & $14.8 \pm 0.5(21.7)$ & $68.2 \pm 2.4 \mathrm{~b}$ \\
Populus simonii & $5.9 \pm 0.3(10.4)$ & $17.0 \pm 1.7(29.9)$ & $22.7 \pm 3.1(39.8)$ & $13.0 \pm 1.5(22.9)$ & $57.0 \pm 6.7 \mathrm{~b}$ \\
\hline
\end{tabular}

Data represent the mean \pm standard deviation, basing on measured tree $D$ and $H$ in Table 1 and the equations described in Table 2 . Significant differences among plantations are indicated with lowercase letters $(\alpha=0.05)$. Values in brackets are percentages of component biomass to the total tree biomass 
Fig. 1 Tree biomass and C storage of different plantations. Significant differences in tree biomass or tree $\mathrm{C}$ storage among plantations are indicated with lowercase letters $(\alpha=0.05)$. Vertical lines are standard deviation

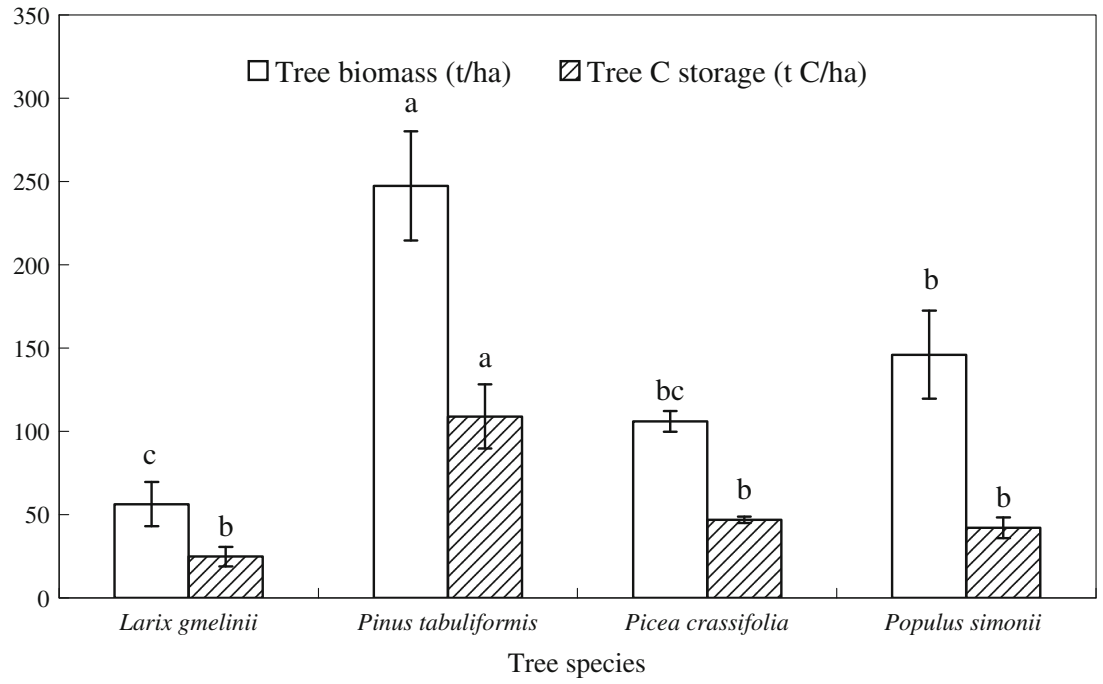

shrub components, $\mathrm{C}$ fractions of leaf $(43.7 \pm 1.8 \%)$ and branch $(43.0 \pm 1.1 \%)$ were higher than that of root $(40.8 \pm$ $2.6 \%)(P<0.05)$. In addition, herb $\mathrm{C}$ fraction in aboveground biomass was significantly higher than that in belowground biomass $(P<0.05)$. C storage of understory vegetation ranged between $0.5 \mathrm{t} \mathrm{C} /$ ha and $1.0 \mathrm{t} \mathrm{C/ha} \mathrm{among} \mathrm{different} \mathrm{plantations.} \mathrm{The}$ shrub:herb ratio of $\mathrm{C}$ storage was much higher in Populus simonii plantation (13.4) than that in other plantations (Fig. 3).

\subsection{C storage of litter layer}

Biomass of litter ranged from $9.7 \mathrm{t} / \mathrm{ha}$ to $31.6 \mathrm{t} / \mathrm{ha}$ and significantly differed among the four plantations $(F=11.116, P=$ 0.003 ) (Table 6). Picea crassifolia plantation had significantly higher litter biomass than other plantations $(P<0.05)$, while Populus simonii plantation had the lowest one. Litter $\mathrm{C}$ storage ranged between $2.4 \mathrm{t} \mathrm{C} /$ ha and $7.9 \mathrm{t} \mathrm{C}$ ha. The annual increment of litter $\mathrm{C}$ storage decreased in the following sequence, Picea crassifolia $>$ Larix gmelinii, Pinus tabuliformis $>$ Populus simonii $(F=30.262, P=0.003)$.

\subsection{SC fraction and storage}

The mean values of SC fraction decreased with increasing of soil depth (Fig. 4). This pattern was particularly evident in
Pinus tabuliformis plantation. SC fraction decreased by $75.5 \%$ from $0-10 \mathrm{~cm}$ to $50-100 \mathrm{~cm}$ in Pinus tabuliformis plantation. Throughout the soil profile, SC fraction varied among the plantations, and decreased in the order Picea crassifolia $>$ Larix gmelinii $>$ Populus simonii $>$ Pinus tabuliformis. Picea crassifolia plantation had the highest SC storage (411 t C/ha), followed by Larix gmelinii (342 t C/ha) and Populus simonii (283 t C/ha) plantations (Table 5). Pinus tabuliformis plantation had extremely lower SC storage than other plantations $(P<0.05)$. SC sequestration rates were higher in Populus simonii and Picea crassifolia plantations, while lower in Larix gmelinii and Pinus tabuliformis plantations.

\subsection{Forest ecosystem C storage}

We compared the $\mathrm{C}$ storage in live biomass, litter, soil, and the whole ecosystem (Fig. 5). There were significant differences in forest ecosystem $\mathrm{C}$ storage among the plantations ( $F=$ 30.993, $P<0.001)$. Picea crassifolia plantation had significantly higher litter $\mathrm{C}$ storage $(7.9 \mathrm{t} \mathrm{C/ha)}, \mathrm{SC}$ storage $(411 \mathrm{t}$ $\mathrm{C} / \mathrm{ha}$ ), and ecosystem $\mathrm{C}$ storage (469 t C/ha) than the other plantations $(P<0.05)$. In contrast, Pinus tabuliformis had the lowest ecosystem $\mathrm{C}$ storage $(281 \mathrm{t} \mathrm{C} / \mathrm{ha})$ but the highest biomass $\mathrm{C}$ storage $(110 \mathrm{t} \mathrm{C/ha})$. SC storage proportion of the

Table 4 Tree component $\mathrm{C}$ fraction (\%) of different plantations

\begin{tabular}{|c|c|c|c|c|c|}
\hline Component & Larix gmelinii & Pinus tabuliformis & Picea crassifolia & Populus simonii & Mean \\
\hline Leaf & $45.3 \pm 0.8$ & $47.9 \pm 0.7$ & $46.0 \pm 0.7$ & $44.0 \pm 1.6$ & $46.8 \pm 1.3 \mathrm{a}$ \\
\hline Branch & $47.6 \pm 1.2$ & $46.3 \pm 2.4$ & $44.9 \pm 2.9$ & $44.5 \pm 2.4$ & $45.6 \pm 2.0 \mathrm{ab}$ \\
\hline Trunk & $46.9 \pm 1.3$ & $44.2 \pm 1.2$ & $45.3 \pm 2.0$ & $45.6 \pm 0.4$ & $45.1 \pm 1.7 \mathrm{~b}$ \\
\hline Root & $47.4 \pm 0.2$ & $44.0 \pm 0.5$ & $44.3 \pm 1.0$ & $43.8 \pm 0.6$ & $44.4 \pm 1.3 b$ \\
\hline Mean & $45.8 \pm 1.6 \mathrm{a}$ & $45.8 \pm 2.4 \mathrm{a}$ & $45.5 \pm 1.5 \mathrm{a}$ & $44.9 \pm 1.6 \mathrm{a}$ & \\
\hline
\end{tabular}

Data represent the mean \pm standard deviation. Significant differences among components or tree species are indicated with lowercase letters $(\alpha=0.05)$ 
Fig. 2 Component biomass of understory vegetation [shrub (A) and herb (B)] of different plantations. Significant differences in shrub and herb component biomass among plantations are indicated with lowercase letters $(\alpha=0.05)$. Vertical lines are standard deviation
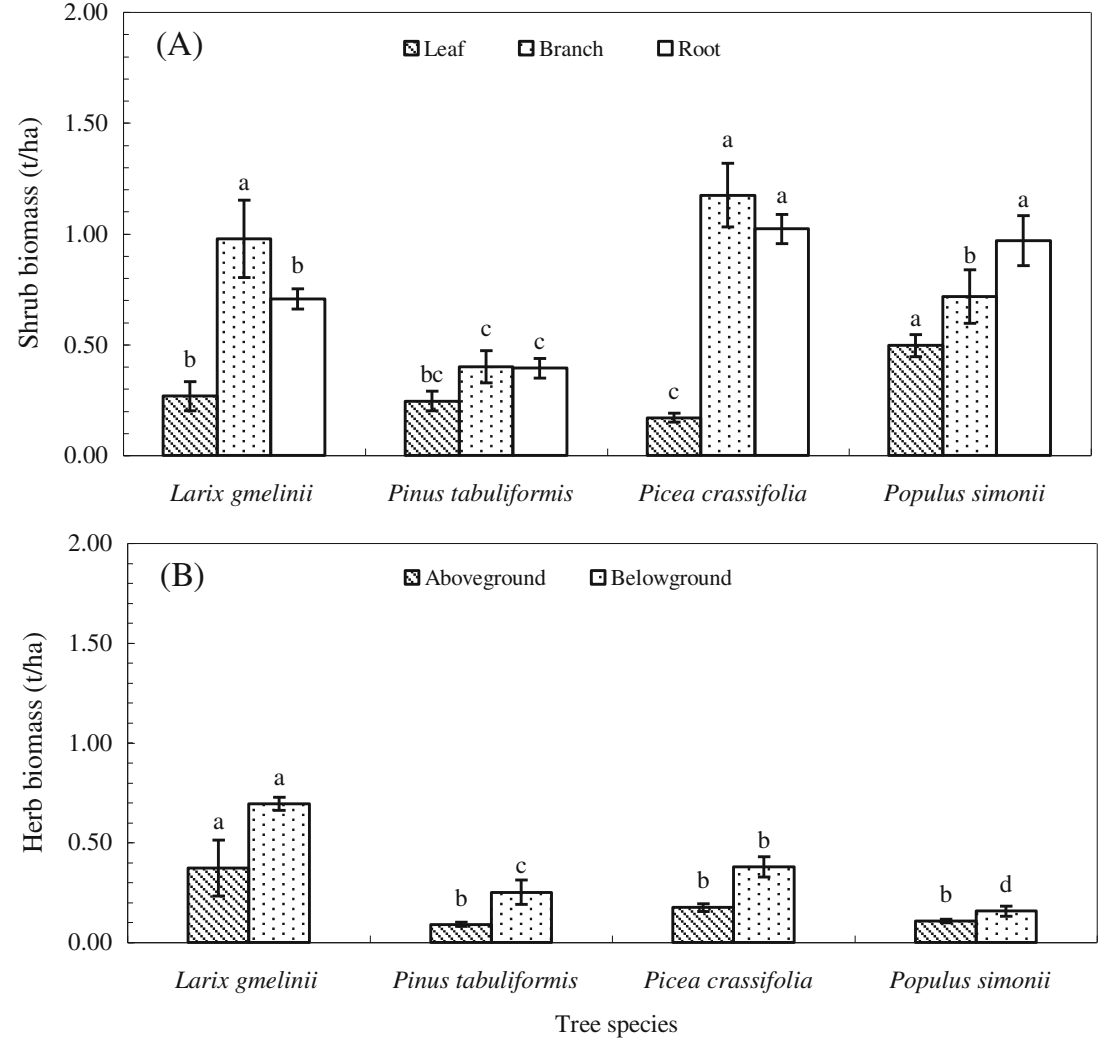

ecosystem C storage ranged from 59.5 to $91.1 \%$, while litter $\mathrm{C}$ storage proportion ranged from 0.7 to $1.5 \%$.

\section{Discussion}

There were significant differences in tree biomass among the four plantations. The tree biomass was in the order of Pinus tabuliformis $>$ Picea crassifolia $>$ Populus simonii $>$ Larix gmelinii (Fig. 1). The interspecific differences in tree biomass were mainly caused by inherent variations in growth rates
(Houghton 2005). In this study, Pinus tabuliformis had the highest tree biomass $(247 \mathrm{t} / \mathrm{ha})$ and growth rate $(2.7 \pm 0.4 \mathrm{~kg} /$ tree/year). As reported by Zheng and Shangguan (2007), Pinus tabuliformis kept a stable photosynthetic rate over a range of climates. Also, its strong drought tolerance was exhibited in the leaf morphological acclimation, such as leaf mass per area, chlorophyll content and etc. Therefore, Pinus tabuliformis was well-adapted to the semiarid Loess Plateau. In addition, the tree biomass of Pinus tabuliformis plantation was higher than the mean biomass (73-184t/ha) observed by previous research (Ma 1989). This may be due to the high

Table $5 \mathrm{C}$ fraction (\%) of understory vegetation in different plantations

\begin{tabular}{lllll}
\hline & Larix gmelinii & Pinus tabuliformis & Picea crassifolia & Populus simonii \\
\hline Shrub & & & & \\
$\quad$ Leaf & $43.3 \pm 1.3$ & $45.0 \pm 1.0$ & $41.6 \pm 2.2$ & $45.4 \pm 1.0$ \\
Branch & $43.7 \pm 0.2$ & $43.4 \pm 0.8$ & $41.9 \pm 0.8$ & $44.0 \pm 0.5$ \\
Root & $41.7 \pm 1.4$ & $41.8 \pm 0.3$ & $36.3 \pm 1.9$ & $41.1 \pm 0.2$ \\
Mean & $42.9 \pm 1.3 \mathrm{a}$ & $43.4 \pm 1.5 \mathrm{a}$ & $39.9 \pm 3.1 \mathrm{~b}$ & $43.5 \pm 2.0 \mathrm{a}$ \\
Herb & & & & $43.7 \pm 1.8 \mathrm{a}$ \\
Aboveground & $41.4 \pm 1.0$ & $37.4 \pm 3.4$ & $35.4 \pm 0.8$ & $34.7 \pm 1.4$ \\
Belowground & $39.8 \pm 4.4$ & $31.6 \pm 1.1$ & $31.0 \pm 3.0$ & $33.9 \pm 0.8$ \\
Mean & $40.6 \pm 6.9 \mathrm{a}$ & $34.5 \pm 9.0 \mathrm{~b}$ & $33.2 \pm 8.1 \mathrm{~b}$ & $34.3 \pm 5.9 \mathrm{~b}$ \\
\hline
\end{tabular}

Data represent the mean \pm standard deviation. Significant differences among components or tree species are indicated with lowercase letters $(\alpha=0.05)$ 
Fig. 3 Understory C storage of different plantations. Significant differences among plantations are indicated with lowercase letters $(\alpha=0.05)$. Vertical lines are standard deviation

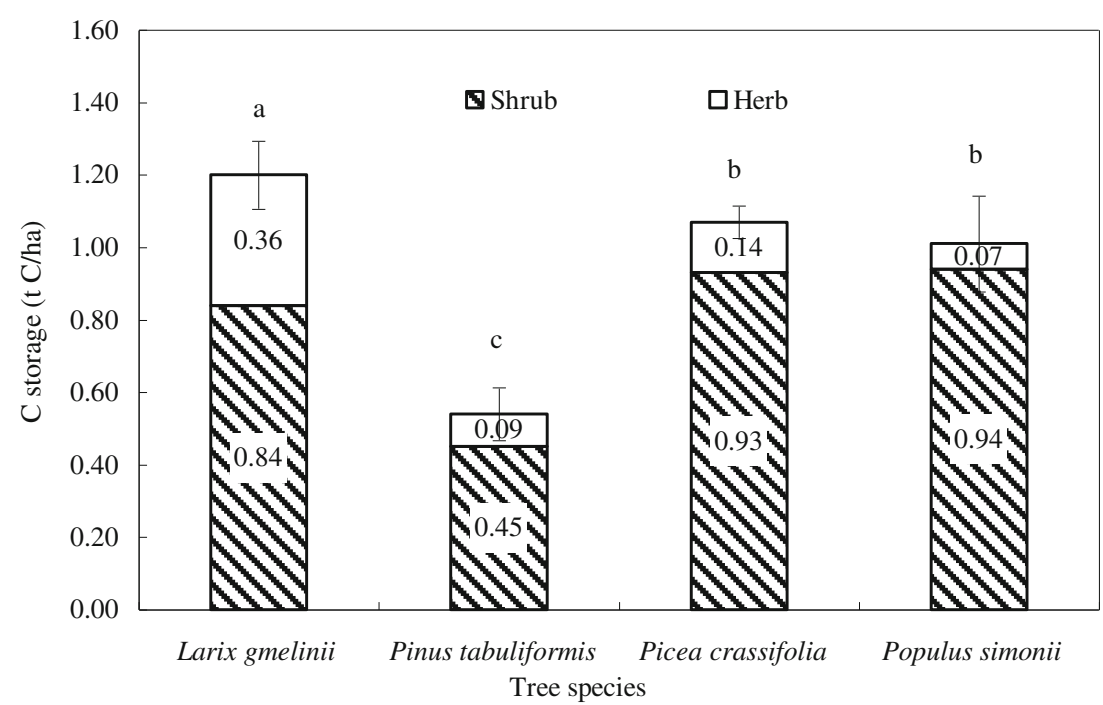

stand density $(2,830 \pm 256$ tree/ha), which could maximize the tree biomass (Jandl et al. 2007).

$\mathrm{C}$ storage of understory layer decreased in an inverse trend to that of tree layer (Fig. 2). There was a significant negative correlation between understory $\mathrm{C}$ storage and tree $\mathrm{C}$ storage ( $r=-0.836, P=0.001)$. The result can be partly attributed to the increasing of tree cover canopy with the increment of tree biomass. An increased canopy closure resulted in a dramatic change in understory microclimatic condition and resources availability (Abdallah and Chaieb 2012). For example, plantations characterized by a higher canopy closure prevented larger shares of sunlight from reaching the understory layer (von Arx et al. 2012). The photosynthesis of understory vegetation was suppressed, and the biomass and $\mathrm{C}$ accumulation was decreased. Moreover, a lower air temperature caused by a high canopy closure, particularly during the growing season, elevated metabolic rates of understory vegetation (Holst et al. 2004). High metabolic rates brought the relative lower biomass accumulation.

In this study, Populus simonii plantation had significantly lower litter C storage than Larix gmelinii and Picea crassifolia plantations (Table 6). To explain this result, the deciduous leaf

Table 6 Litter biomass, $\mathrm{C}$ fraction and $\mathrm{C}$ storage and annual increment in litter $\mathrm{C}$ storage of different plantations

\begin{tabular}{lllll}
\hline Tree species & $\begin{array}{l}\text { Biomass } \\
(\mathrm{t} / \mathrm{ha})\end{array}$ & $\begin{array}{l}\mathrm{C} \text { fraction } \\
(\%)\end{array}$ & $\begin{array}{l}\mathrm{C} \text { storage } \\
(\mathrm{t} \mathrm{C} / \mathrm{ha})\end{array}$ & $\begin{array}{l}\text { Annual C storage } \\
\text { increment } \\
(\mathrm{t} \mathrm{C} / \mathrm{ha} / \mathrm{year})\end{array}$ \\
\hline Larix gmelinii & $27.6 \pm 5.1 \mathrm{a}$ & $21.2 \pm 4.0 \mathrm{a}$ & $5.7 \pm 0.5 \mathrm{~b}$ & $0.12 \pm 0.01 \mathrm{~b}$ \\
Pinus tabuliformis & $12.0 \pm 1.5 \mathrm{~b}$ & $30.2 \pm 2.6 \mathrm{a}$ & $3.6 \pm 0.6 \mathrm{c}$ & $0.11 \pm 0.02 \mathrm{~b}$ \\
Picea crassifolia & $31.6 \pm 5.7 \mathrm{a}$ & $25.9 \pm 6.4 \mathrm{a}$ & $7.9 \pm 1.0 \mathrm{a}$ & $0.16 \pm 0.02 \mathrm{a}$ \\
Populus simonii & $9.7 \pm 2.1 \mathrm{bc}$ & $25.8 \pm 5.1 \mathrm{a}$ & $2.4 \pm 0.6 \mathrm{c}$ & $0.06 \pm 0.01 \mathrm{c}$ \\
\hline
\end{tabular}

Data represent the mean \pm standard deviation. Significant differences among plantations are indicated with lowercase letters $(\alpha=0.05)$ litter exhibited a greater decomposition rate than other tree leaf litter (Schulp et al. 2008). Its greater decomposition rate was mainly caused by the high concentration of soluble carbohydrates and low concentration of lignin (Hobbie et al. 2000). In addition, Populus simonii plantation was located in a lower altitude where there was a higher temperature to accelerate the decomposition (Table 1). Picea crassifolia plantation had the highest litter $\mathrm{C}$ storage among plantations. This was attributed to the species-specific influence on the C-mineralization patterns in litter layer. It was reported that nitrification of litter layer beneath the spruce stand was very low (Trum et al. 2011). Thus, the tree species had played an important role in $\mathrm{C}$ accumulation in litter layers.

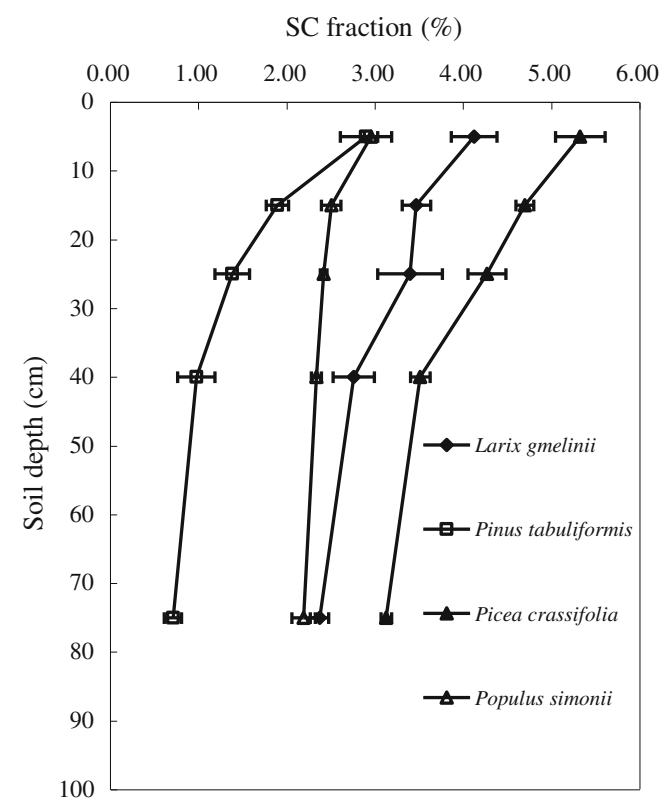

Fig. 4 SC fraction $(0-100 \mathrm{~cm})$ of different plantations. Horizontal lines are standard deviation 
Fig. 5 Ecosystem C storage of different plantations. Significant differences in live biomass, litter, soil and ecosystem $\mathrm{C}$ storage among plantations are indicated with lowercase letters $(\alpha=0.05)$. Vertical lines are standard deviation

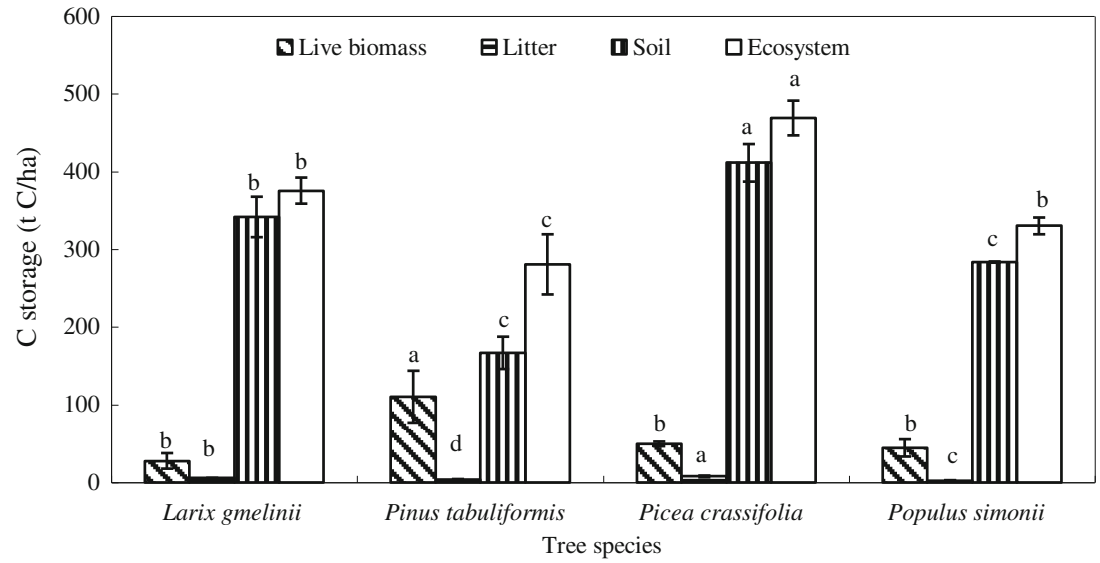

SC sequestration rate in the Populus simonii plantation was higher than that in the three coniferous plantations (Table 7). Differences in SC sequestration among tree species may be attributable to the various $\mathrm{C}$ input or output patterns (Jandl et al. 2007). For this study, the most determinant factor is the rate of transfer of $\mathrm{C}$ from litter and root to soil. Litterfall from the Populus simonii plantation decayed faster than that from other plantations due to its chemical composition and microclimatic condition. Moreover, deciduous trees presented a deeper rooting pattern than the coniferous trees, which resulted in a higher rate of root production and turnover (Johnson 1992). The greater $C$ input from both litter and root decomposition sequestered a higher $\mathrm{SC}$ in the Populus simonii plantation. In contrast, Larix gmelinii and Pinus tabuliformis plantation had negative SC sequestration rate (Table 7). The explanation was that Larix gmelinii and Pinus tabuliformis planting had disturbed soil properties and stimulated the mineralization of SC. These losses were not offset by the low C input from conifer litter within a brief period (Pérez-Cruzado et al. 2012). The result was in agreement with previous findings (Farley et al. 2004; Laganière et al. 2010). The researches suggested that $\mathrm{SC}$ was decreased in coniferous plantations at the decade scale. SC accumulation occurred until the soil reached a new equilibrium between $\mathrm{C}$ input and $\mathrm{C}$ output.

In the study, SC storage was demonstrated as the largest $\mathrm{C}$ pool in the ecosystem throughout the four plantations (Fig. 4). The differences in ecosystem $\mathrm{C}$ storage among plantations

Table 7 SC storage and sequestration rates of different plantations

\begin{tabular}{llll}
\hline Tree species & $\begin{array}{l}\text { Plantation } \\
\text { (t C/ha) }\end{array}$ & $\begin{array}{l}\text { Abandoned land } \\
\text { (t C/ha) }\end{array}$ & $\begin{array}{l}\text { SC sequestration rate } \\
\text { (t C/ha/year) }\end{array}$ \\
\hline Larix gmelinii & $342 \pm 26 \mathrm{~b}$ & $395 \pm 87$ & -1.16 \\
Pinus tabuliformis & $167 \pm 21 \mathrm{~d}$ & $341 \pm 96$ & -9.86 \\
Picea crassifolia & $411 \pm 24 \mathrm{a}$ & $263 \pm 36$ & 3.08 \\
Populus simonii & $283 \pm 1 \mathrm{c}$ & $67 \pm 13$ & 8.32 \\
\hline
\end{tabular}

Data represent the mean \pm standard deviation. Significant differences among plantations are indicated with lowercase letters $(\alpha=0.05)$ were mainly determined by the magnitude of SC pool. There was a significant correlation between $\mathrm{C}$ storage in soil and that in ecosystem $(r=0.971, P<0.001)$. This was consistent with the report of Dixon et al. (1994) regarding the soil pool forming the major part of forest $\mathrm{C}$ storage. With the growth of forest trees, there will be more organic matter input to the soil. The ecosystem $\mathrm{C}$ storage will increase with the increment of SC storage ( $\mathrm{Li}$ et al. 2011). Biomass $\mathrm{C}$ storage was the second largest $\mathrm{C}$ pool in the ecosystem. Winjum and Schroeder (1997) reported that mean biomass C storage was $64 \mathrm{t} \mathrm{C} /$ ha in temperate planted forests. With the exception of Pinus tabuliformis, the biomass $\mathrm{C}$ storage of the other three plantations tested in our study was lower than the mean value (64 $\mathrm{t} \mathrm{C/ha).} \mathrm{This} \mathrm{was} \mathrm{probably} \mathrm{attributed} \mathrm{to} \mathrm{the} \mathrm{negative} \mathrm{effect}$ of semiarid climate on tree growth and plant biomass (Silvester and Orchard 1999). However, Li et al. (2003) estimated the mean biomass $\mathrm{C}$ storage was $3.4 \mathrm{t} \mathrm{C} /$ ha in grassland, and $5.7 \mathrm{t} \mathrm{C}$ /ha in agricultural land in China. The biomass $\mathrm{C}$ storage of the four plantations in our study was much higher than the above mentioned ecosystems. Consequently, afforestation carried out in this region pronouncedly increased ecosystem C storage.

Funding Financial support for this research came from the CAS "Strategic Priority Research Program-Climate Change: Carbon Budget and Relevant" (XDA05050202), the State Forestry Bureau Special Fund for Agro-scientific Research in the Public Interest (200904056) and the National Key Laboratory Fund (10502-Z8).

Contribution of the co-authors Yang Gao: measuring the samples, running data analysis and writing the paper. Jimin Cheng: supervising the work. Zhengrui Ma, Yu Zhao and Jishuai Su: collecting the samples.

\section{References}

Abdallah F, Chaieb M (2012) The influence of trees on nutrients, water, light availability and understorey vegetation in an arid environment. Appl Veg Sci 15:501-512 
Cao MK, Woodward FI (1998) Net primary and ecosystem production and carbon stocks of terrestrial ecosystems and their responses to climate change. Glob Chang Biol 4:185-198

Chazdon RL (2008) Beyond deforestation: restoring forests and ecosystem services on degraded lands. Science 320:1458-1460

Chinese Editorial Committee of Soil Analysis (1996) Soil physical and chemical analysis and description of soil profile. China State Standards Press, Beijing, In Chinese

Díaz-Pinés E, Rubio A, Van Miegroet H, Montes F, Benito M (2011) Does tree species composition control soil organic carbon pools in Mediterranean mountain forests? For Ecol Manag 262:1895-1904

Dixon RK, Brown S, Houghton RA, Solomon AM, Trexler MC, Wisniewski J (1994) Carbon pools and flux of global forest ecosystems. Science 263:185-190

Fang JY, Chen AP, Peng CH, Zhao SQ, Ci LJ (2001) Changes in forest biomass carbon storage in China between 1949 and 1998. Science 292:2320-2322

Farley KA, Kelly EF, Hofstede RGM (2004) Soil organic carbon and water retention following conversion of grasslands to pine plantations in the Ecuadoran Andes. Ecosystems 7:729-739

Finzi AC, Van Breemen N, Canham CD (1998) Canopy tree soil interactions within temperate forests: Species effects on soil carbon and nitrogen. Ecol Appl 8:440-446

Guo Z, Fang J, Pan Y, Birdsey R (2010) Inventory-based estimates of forest biomass carbon stocks in China: A comparison of three methods. For Ecol Manag 259:1225-1231

Hobbie SE, Schimel JP, Trumbore SE, Randerson JR (2000) Controls over carbon storage and turnover in high-latitude soils. Glob Chang Biol 6:196-210

Holst T, Mayer H, Schindler D (2004) Microclimate within beech standspart II: thermal conditions. Eur J For Res 123:13-28

Houghton RA (2005) Aboveground forest biomass and the global carbon balance. Glob Chang Biol 11:945-958

Jandl R, Lindner M, Vesterdal L, Bauwens B, Baritz R, Hagedorn F, Johnson DW, Minkkinen K, Byrne KA (2007) How strongly can forest management influence soil carbon sequestration? Geoderma 137:253-268

Jobbágy EG, Jackson RB (2000) The vertical distribution of soil organic carbon and its relation to climate and vegetation. Ecol Appl 10:423-436

Johnson DW (1992) Effects of forest management on soil carbon storage. Water Air Soil Pollut 64:83-120

Kaul M, Mohren GMJ, Dadhwal VK (2010) Carbon storage and sequestration potential of selected tree species in India. Mitig Adapt Strateg Glob Chang 15:489-510

Laganière J, Angers DA, Paré D (2010) Carbon accumulation in agricultural soils after afforestation: a meta-analysis. Glob Chang Biol 16: 439-453

Li KR, Wang SQ, Cao MK (2003) Vegetion and soil carbon storage in China. Sci China Ser D 33:72-80, in Chinese with English abstract
Li X, Yi MJ, Son Y, Park PS, Lee KH, Son YM, Kim RH, Jeong MJ (2011) Biomass and carbon storage in an age-sequence of Korean pine (Pinus koraiensis) plantation forests in central Korea. J Plant Biol 54:33-42

Ma QY (1989) A study on the biomass of chinese pine forests. J Beijing For Univ 11:1-10, in Chinese with English abstract

Martius C, Höfer H, Garcia MVB, Römbke J, Förster B, Hanagarth W (2004) Microclimate in agroforestry systems in central Amazonia: does canopy closure matter to soil organisms? Agrofor Syst 60:291304

Paul KI, Polglase PJ, Nyakuengama JG, Khanna PK (2002) Change in soil carbon following afforestation. For Ecol Manag 168:241-257

Pérez-Cruzado C, Mansilla-Salinero P, Rodríguez-Soalleiro R, Merino A (2012) Influence of tree species on carbon sequestration in afforested pastures in a humid temperate region. Plant Soil 353:333-353

Schulp CJE, Nabulars GJ, Verburg PH, de Waal RW (2008) Effect of tree species on carbon stocks in forest floor and mineral soil and implications for soil carbon inventories. For Ecol Manag 256:482-490

Silvester WB, Orchard TA (1999) The biology of kauri (Agathis australis) in New Zealand. I. Production, biomass, carbon storage, and litter fall in four forest remnants. N Z J Bot 37:553-571

Sun Y, Wang DX, Zhang H, Li ZG, Wei YF, Hu TH (2009) Forest ecosystem services and their valuation of Ningxia area. J Northwest A\&F Univ (Nat Sci Edit) 37:91-97, in Chinese with English abstract

Trum F, Titeux H, Ranger J, Delvaux B (2011) Influence of tree species on carbon and nitrogen transformation patterns in forest floor profiles. Ann For Sci 68:837-847

Vesterdal L, Elberling B, Christiansen JR, Callesen I, Schmidt IK (2012) Soil respiration and rates of soil carbon turnover differ among six common European tree species. For Ecol Manag 264:185-196

von Arx G, Dobbertin M, Rebetez M (2012) Spatio-temporal effects of forest canopy on understory microclimate in a long-term experiment in Switzerland. Agric For Meteorol 166:144-155

Winjum JK, Schroeder PE (1997) Forest plantations of the world: their extent, ecological attributes, and carbon storage. Agric For Meteorol 84:153-167

Zhang QZ, Wang CK, Wang XC, Quan XK (2009) Carbon concentration variability of 10 Chinese temperate tree species. For Ecol Manag 258:722-727

Zhang KR, Dang HS, Tan SD, Wang ZX, Zhang QF (2010) Vegetation community and soil characteristics of abandoned agricultural land and pine plantation in the Qinling Mountains, China. For Ecol Manag 259:2036-2047

Zheng SX, Shangguan ZP (2007) Photosynthetic physiological adaptabilities of Pinus tabuliformi and Robinia pseudoacacia in the Loess Plateau Chinese. J Appl Ecol 18:16-22, in Chinese with English abstract 